\title{
DOES INCOME INEQUALITY RAISE AGGREGATE SAVING?
}

\author{
Klaus Schmidt-Hebbel \\ Luis Servén
}

DOCUMENTOS DE TRABAJO DEL BANCO CENTRAL 


\title{
DOES INCOME INEQUALITY RAISE AGGREGATE SAVING?
}

\author{
Klaus Schmidt-Hebbel \\ Manager of Economic Research \\ Central Bank of Chile
}

\author{
Luis Servén \\ The World Bank
}

\begin{abstract}
Resumen
Este trabajo presenta una revisión analítica y empírica de las relaciones entre la distribución del ingreso y el ahorro agregado. La teoría del consumo destaca varios canales directos -- la mayoría de ellos de signo positivo -- a través de los cuales la desigualdad de ingresos puede afectar el ahorro total de los hogares. Sin embargo, la teoría más reciente de economía política señala varios efectos indirectos y negativos de la desigualdad sobre el ahorro, a través de la inversión, el crecimiento y el ahorro público. Este estudio presenta nueva evidencia empírica acerca de la relación entre desigualdad del ingreso y ahorro agregado, basada en información reciente y de mejor calidad para paises industrializados y en desarrollo. Los resultados empíricos, para medidas alternativas de desigualdad y ahorro y distintas especificaciones econométricas empleadas usando datos de corte transversal y de panel para países, no provee sustento estadístico para la noción que la desigualdad de ingresos tenga algún efecto sistemático sobre el ahorro agregado. Este resuiltado es consistente con la ambiguedad teórica destacada arriba pero contradice la literatura empírica existente, que señala una relación positiva entre desigualdad de ingresos y ahorro agregado usando datos de corte transversal de países.
\end{abstract}

\begin{abstract}
This paper reviews analytically and empirically the links between income distribution and aggregate saving. Consumption theory brings out a number of direct channels through which income inequality can affect overall household saving -- positively in most cases. However, recent political-economy theory points toward indirect, negative effects of inequality -- through investment, growth, and public saving -- on aggregate saving. On theoretical grounds the sign of the saving-inequality link is therefore ambiguous. This paper presents new empirical evidence on the relationship between income distribution and aggregate saving, based on a new and improved income distribution database for both industrial and developing countries. The empirical results, using alternative inequality and saving measures and various econometric specifications on both cross-section and panel data, provide no support for the notion that income inequality has any systematic effect on aggregate saving. These findings are consistent with the theoretical ambiguity but contrast with previous empirical literature that found a positive cross-country association between income inequality and aggregate saving.
\end{abstract}

\footnotetext{
We are grateful to Klaus Deininger and Lyn Squire for kindly making available to us their database on income distribution. We thank Aart Kraay, Steve Marglin, Branko Milanovic and Vito Tanzi for useful comments and suggestions on an earlier version. Excellent research assistance by Wanhong $\mathrm{Hu}$ and Faruk Khan is gratefully acknowledged.
} 


\section{Introduction}

If all individuals were identical in all dimensions related to saving decisions (behavior, endowment, and restrictions they face), then aggregate saving would be trivially related to individual saving -- it would just equal the saving of a representative agent multiplied by the population. To determine society's total saving, it would suffice to know the values of the representative agent's income, wealth and so on. In other words, given the total population, aggregate saving would depend only on the aggregate values of variables such as income and wealth.

If individuals are instead heterogeneous, however, this simple relationship ceases to hold. To be more precise, only under very particular (and restrictive) forms of heterogeneity do aggregate consumption and saving depend exclusively on aggregate quantities. ${ }^{1}$ In the more general, and realistic, case in which individual heterogeneity can take arbitrary forms, aggregate consumption and saving patterns inevitably reflect the dissimilar behavior of heterogeneous agents that differ in their preferences, resources and/or institutional constraints. This, of course, has long been recognized by consumption theory; indeed, consumption and saving are among the few areas in macroeconomics where theoretical developments have occasionally left the safe haven of representative-agent models to venture into the wilderness of agent heterogeneity, collecting along the way valuable analytical and empirical insights -- such as those derived, for example, from the life-cycle consumption model.

One particular dimension of heterogeneity that has received increased attention from the macroeconomic viewpoint in recent years is that of income distribution. Recent analytical and empirical work has focused on the relationship between income inequality, growth and investment. ${ }^{2}$ Less attention has been paid, however, to the links between income distribution and saving.

It is important to clarify what distribution of income one is talking about, because different concepts have been considered in the literature. Early research focused on functional income distribution, which can behave very differently from personal income distribution. Further, among the class of personal distributions of income, household and individual income distribution typically differ significantly. Finally, the precise income definition also matters. For example, in a world of otherwise identical individuals that

${ }^{1}$ For a formal discussion of the circumstances under which the economy can be summarized by a "representative consumer", see Mas-Colell, Whinston and Green (1996). See also Kirman (1992) for a recent sharp criticism of the representative-agent paradigm.

${ }^{2}$ See for example Galor and Zeira (1993), Alesina and Rodrik (1994), Persson and Tabellini (1994), Perotti (1995), and Alesina and Perotti (1996). 
differ only by age (but have the same lifetime income), inequality in current income would merely reflect the different stage of the life cycle in which different individuals find themselves.

Much of the historical literature on distribution and aggregate saving - comprising both neoclassical and Keynesian growth models -- has focused on functional income distribution. Yet neoclassical consumption theory brings out a number of channels through which inequality in the personal distribution of income affects directly the total volume of personal (i.e. individual or household) saving. Most of these mechanisms (but not all) result in a positive relationship between income inequality and personal saving. However, recent political-economy theory underscores indirect links from inequality -- through investment, growth, and public saving -- to aggregate (household plus corporate plus public) saving, that should result in a negative relationship. Therefore, the sign of the overall impact of inequality on aggregate saving is

ambiguous on theoretical grounds, and becomes largely an empirical matter.

Most of the empirical literature on the links between personal income distribution and personal saving based on cross-section micro data suggests a positive relation between personal income inequality and overall personal saving. In tum, the evidence from aggregate (typically, cross-country) data is more mixed. Some studies also find positive effects of personal income inequality on aggregate saving, but others do not. Reconciling these conflicting results is difficult because empirical studies based on macro data use widely different samples and specifications, different measures of saving and inequality and, in

most cases, income distribution information of questionable quality.

This paper reexamines the empirical evidence from macro data on the links between the distribution of personal income and aggregate saving, controlling for relevant saving determinants. It provides an encompassing framework and a robustness check for previous empirical studies, and extends them in five dimensions: (i) testing altemative saving specifications, (ii) using alternative inequality and saving measures, (iii) making use of newer, better, and larger databases, (iv) conducting estimations jointly and separately for industrialized and developing countries, and (v) applying various estimation techniques on both cross-country and panel data. On the whole, we do not find any consistent effect of income inequality on aggregate saving -- a result that accords with the theoretical ambiguity.

The paper is organized as follows. Section 2 presents the stylized facts on saving, income, growth, and income distribution using data for a large number of industrial and developing countries. Section 3 provides a brief survey of altemative views of saving determination, with emphasis on the saving consequences of different income distribution profiles. Section 4 reviews previous empirical studies of the 
impact of income distribution on saving, and Section 5 presents new econometric evidence using our data set. Finally, Section 6 concludes.

\section{Saving and Distribution: the Stylized Facts}

\section{The Data}

We begin with a brief summary of our data. Individual variable definitions and sources are reported in the Data Appendix. Our basic information are cross-country time-series data for the 1965 1994 period from the World Bank macroeconomic and social databases, and income distribution data from a new World Bank database recently assembled by Deininger and Squire (1996). The cross-country data presented in this section was constructed by computing the 1965-94 country averages of the raw data. For some countries some of the variables of interest (notably those related to income distribution) are not available every year of the 1965-94 period; country averages were computed using the available observations. Finally, in some empirical experiments below the cross-country data was complemented with information from Barro and Lee's (1993) database. Thus, apart from the income distribution data, our sources are standard and well-known. Hence we describe briefly the main features of the income distribution database, and in particular the selection of the subsample used in this paper.

Deininger and Squire's (1996) new cross-country time-series database on income inequality measures represents a major improvement in rigor, quality, and coverage over preceding data sets -including in particular those used in the previous literature on saving and income distribution. Unlike in other existing databases, a clear distinction is made between income-based and expenditure-based inequality measures, as well as between household-based and individual-based, and the underlying primary data are checked for three important quality criteria: they have to be based on household or individual surveys (not on national accounts), their coverage has to be comprehensive (i.e., based on nation-wide samples), and measurement of income (or expenditure) has to be comprehensive as well (including all income or expenditure categories).

While the total number of country-year observations in Deininger-Squire is 2621 , applying the three latter quality criteria reduces the number to 682 high-quality country-year observations, corresponding to 108 countries and years within the period 1890-1995. For these observations, both Gini coefficients and income shares by population quintiles are available.

Of the latter 682 observations we include in our subsample only those 468 country-year observations (corresponding to 82 countries) that fall into the 1965-94 period (the one for which we have 
complete macroeconomic data). However, this set includes observations based on income data along with others based on expenditure data. In order to make the Gini coefficients from income- and expenditurebased data comparable (income is typically more concentrated than expenditure) we follow the simple procedure suggested by Deininger and Squire by adding a constant equal to 6.7 to the expenditure-based coefficients. The latter figure is the average difference between income and expenditure-based Gini coefficients reported by Deininger and Squire, for those country-year observations for which both data are available. However, it is methodologically much less clear what type of correction should be applied to the expenditure-based income shares by quintiles. Hence, we opt for dropping them and restrict our database of income shares only to income-based data.

For our cross-country dataset based on 1965-94 averages for each country we impose an additional requirement to achieve a minimum of time representation: countries are included only if they have at least one observation in each of the following two 15-year periods: 1965-79 and 1980-94. This leaves us with 52 country observations. Table 1 presents a summary of the total number of observations in terms of country-years (for our panel dataset) and country averages (for our cross-country dataset), for Gini coefficients and share ratios and by country groups:

Unless otherwise noted, here and in the rest of the paper we use the terms 'income inequality' and 'income distribution' for all samples and statistical results, even when they refer to Gini coefficients based on both income and expenditure-based information. ${ }^{3}$ Likewise, we use the term 'saving' ('saving ratio') to refer to gross national saving (respectively, its ratio to GNP). We choose national saving and national product data as the relevant variables because they are closer to the relevant units (households or individuals) for which income distribution data is available than the domestic saving and domestic product measures. In this respect we differ from most previous empirical studies, that are based on the less adequate domestic measures.

A final caution relates to measurement error. As is well known, this is a central problem in empirical studies of saving, due not only to the inadequacy of the very saving concept used by the National Accounts (which, for example, exclude capital gains from the definition of income, and treat human capital expenditures as consumption) but also to the unreliability of measured saving, which stems largely from the fact that saving is often computed as the residual from another residual (consumption). The upshot is that

${ }^{3}$ The empirical results based on the smaller sub-sample of income-based Gini coefficients were very similar to those reported below, which are based on the larger sample comprising both income-based and adjusted expenditure-based Ginis. To save space, we only report the latter. 
saving measures may contain large errors, particularly in developing countries where the statistical apparatus involved in the collection of household data is likely to be weaker. ${ }^{4}$ Measurement error is likely to be an even more serious problem in the case of income distribution statistics. The latter are primarily derived from household survey data, which typically understate the income of the richer households. As a result, income inequality is likely to be underestimated .- and probably more so in poorer countries.

\section{The stylized facts}

Keeping in mind the features and limitations of the available data discussed above, we turn next to the review of the stylized facts present in the data. To save space and keep comparability with the previous literature, the discussion focuses only on the cross-country dimension of the data.

We first provide summary statistics for our income distribution data (a detailed description of the full dataset is in Deininger and Squire 1996). Table 2 presents means and standard deviations of three conventional indicators of inequality: the Gini coefficient, the ratio between the income shares of the richest 20 percent and poorest 40 percent of the population, and the income share of the 'middle class', defined as the middle 60 percent of the population (often used as an indicator of equality). The statistics are computed for the world, industrial countries, and developing countries. As the table shows, developing countries are more unequal than industrial countries by any of the three indicators presented, and show also a larger dispersion in their levels of inequality.

Let us examine now the empirical association between the saving ratio and some important saving determinants. We start with the relationship between saving and the level of development -- as measured by real per capita GNP. Figure 1 presents the scatter plot of the 1965-1994 averages of these two variables for the sample countries. ${ }^{5}$ In the figure, countries appear clustered in rough correspondence to their development level. On average, saving rates are lower for developing countries than for industrial countries. Saving rates tend to rise with per capita income: the correlation coefficient between the two variables is .36 (Table 3), significantly different from zero at the 5 percent level, and is even higher (.48)

${ }^{4}$ Biases may arise in saving regressions as a result of measurement errors in saving, because the errors are likely to be correiated with saving determinants in general and income in particular. Recent discussions of measurement problems in saving data and analyses include Deaton (1989), Lipsey and Tice (1989), Srinivasan (1994), and Schmidt-Hebbel, Servén and Solimano (1996). picture.

${ }^{5}$ Using per capita income at the initial year of the sample instead of its average value yields a very similar 
among developing countries. A similar association has been found in a number of empirical studies of saving (e.g., Collins 1991; Schmidt-Hebbel, Webb and Corsetti 1992; Carroll and Weil 1994; Masson, Bayoumi and Samiel 1995; Edwards 1995).

The figure also suggests that at high levels of per capita income saving ratios appear to level off -i.e., the relationship is not linear, and possibly not even monotonic. As a more formal check on this, the solid line in Figure 1 plots the fitted values from regressing the saving rate on a quadratic polynomial in per capita income; the estimated coefficients are significant at conventional levels. The fitted curve shows that the positive association between saving and development appears indeed to be confined to the early stages of development, ceases to hold at about $\$ 10,000$ per capita GNP (in 1987 US\$), and turns into a negative association at higher income levels.

A second stylized fact is the strong positive association between saving ratios and real per capita growth, which has been amply documented in cross-country empirical studies. ${ }^{6}$ However, its structural interpretation remains controversial, as it has been viewed both as proof that growth drives saving (e.g.. Modigliani 1970, among many other studies) and that saving drives growth through the saving-investment link (e.g., Levine and Renelt 1992; Mankiw, Romer and Weil 1992). ${ }^{7}$ As Figure 2 and Table 2 show, our data conform to these findings. Aggregate saving ratios and real per capita GNP growth are positively associated, and as Table 3 shows their correlation coefficient equals .50, significantly different from zero at the 5 percent level.

Is the association between saving and income distribution as clear-cut as that between saving and income (or its growth rate) ? Figure 3, which plots saving ratios against Gini coefficients of income distribution, shows no clear pattern. The full-sample correlation between both variables is in fact negative $(-0.32$, significant at the 5 percent level), suggesting a negative effect of income concentration on aggregate saving. As the picture also suggests, however, the correlation pattern is rather different in the industrial (.10) and developing-country $(-.20)$ subsamples; in neither is it significantly different from zero.

The above facts lead to the much-discussed relationship between income inequality and level of development -- with the latter measured as before by real per capita GNP. According to the well-known finding by Kuznets (1955), the relationship between these variables follows an inverted-U shape: inequality

${ }^{6}$ See for example Modigliani (1970), Maddison (1992), Bosworth (1993) and Carroll and Weil (1994).

${ }^{7}$ On the saving-growth causality see the recent overviews by Carroll and Weil (1994), Deaton (1995), and Schmidt-Hebbel, Serven and Solimano (1996). 
rises in the early stages of development, and then decreases as per capita income continues to rise. This stylized fact has been replicated to varying extent in a number of cross-country studies (for recent examples see Bourguignon and Morrison 1990, and Clarke 1992), but its interpretation is far from clear (see Adelman and Robinson 1989, for a discussion). ${ }^{8}$ Time-series data provide much less support for a Kuznets-type relation. ${ }^{9}$

Figure 4 shows that our cross-country sample fits the Kuznets curve. Keeping with convention, the figure plots Gini coefficients against the log of per capita income (with both variables measured by their 1965-94 averages). The curved line in the graph depicts the fitted values from regressing the Gini coefficient on the log of per capita income and its square; the estimated regression coefficients are highly significant. As can be seen from the figure, developing countries account for the upward-sloping portion of the empirical curve, and industrial countries cluster along the declining portion.

One methodological issue that arises is whether the above findings are sensitive to our choice of the Gini coefficient as the relevant inequality statistic. A number of altemative indicators are found in the literature -- e.g., Theil's index, the coefficient of variation of income across households, the income share of the poorest 20 or 40 percent of the population, the ratio of the latter to the income share of the richest 20 percent, or the income share of the middle class. ${ }^{10}$ Among all them, the Gini coefficient, Theil's index or the coefficient of variation are generally preferable because they use more information than the commonlyencountered quintile-based indicators. At the same time, the Gini index has the well-known drawback that it is not uniquely related to the shape of the underlying distribution, so that very different redistribution schemes can be reflected in the same change in the Gini coefficient. Finally, income shares (in levels) and Gini coefficients may pose cross-country comparability problems more severe than those derived from the use of share ratios (Deininger and Squire, 1996).

In practice, however, the informational content of all these indicators is usually very similar, as shown by the fact that they typically are very highly correlated -- even though they may yield different

${ }^{8}$ As is well known, Kuznets' explanation of his empirical finding was based on the shift of population from traditional to modern activities. See Anand and Kanbur (1993) for an analytical reassessment of this view.

${ }^{9}$ For instance Fields (1991), using time-series data for low and middle-income countries, concludes that inequality increases as often as it decreases in low-income countries .- and the same holds for middle-income countries.

\footnotetext{
${ }^{10}$ For a discussion of the properties of these indices see for example Cowell (1977).
} 